\title{
First Total Synthesis and Investigation of the X-ray Crystal Struc- ture of the Pyrano[3,2-a]carbazole Alkaloid Clausenalansine A
}

\author{
Valerie Lösle ${ }^{a}$ \\ Olga Kataevab \\ Hans-Joachim Knölker*a \\ a Faculty of Chemistry, Technische Universität Dresden, Berg- \\ straße 66, 01069 Dresden, Germany \\ hans-joachim.knoelker@tu-dresden.de \\ ${ }^{\mathrm{b}}$ A. E. Arbuzov Institute of Organic and Physical Chemistry, \\ FRC Kazan Scientific Center, Russian Academy of Sciences, \\ Arbuzov Str. 8, Kazan 420088, Russian Federation
}

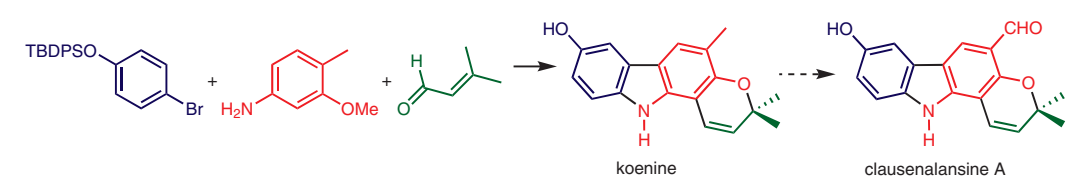

Dedicated to Professor Tomáš Hudlický on the occasion of his $71^{\text {st }}$ birthday

\begin{abstract}
Received: 07.09.2020
Accepted after revision: 06.10.2020

Published online: 05.11 .2020

DOI: 10.1055/s-0040-1706551; Art ID: ss-2020-z0480-op

Abstract We describe the first total synthesis of the recently discovered pyrano[3,2-a]carbazole alkaloid clausenalansine $A$. The synthetic strategy for the construction of this formylpyrano[3,2-a]carbazole is based on a sequence of Buchwald-Hartwig coupling, palladium(II)-catalyzed oxidative cyclization, Lewis acid promoted annulation of the pyran ring, and chemoselective oxidation of a methyl to a formyl group.
\end{abstract}

Key words carbazoles, alkaloids, annulation, catalysis, cyclization, natural products, total synthesis, palladium

Carbazole alkaloids have been the focus of research for a long time because of their broad range of useful biological activities. They have been isolated from various natural sources including terrestrial plants, microorganisms, slime molds, and algae. ${ }^{1,2}$ Among the former, especially plants of the genera Murraya, Clausena, and Glycosmis, all belonging to the family Rutaceae, were found to be extremely rich in diverse carbazole alkaloids. Biogenetically, all the carbazole natural products from terrestrial plants derive from 3methylcarbazole as parent compound. Subsequent oxygenation at different positions of the carbazole framework, oxidation of the methyl group, and prenylation or geranylation followed by annulation of additional rings along the biogenetic pathway provide the broad structural variety of carbazoles found in plants of the Rutaceae family. ${ }^{2}$ Over the past decades, many examples of monooxygenated pyrano[3,2-a]carbazole alkaloids with a $C_{1}$ moiety at the 3-position as represented by compounds 1-4 have been isolated from nature (Figure 1). ${ }^{3-6}$ Only very recently, Fu and coworkers described the isolation of the novel clausenalansine A (1), along with the previously known pyrano[3,2a]carbazoles clauraila E $(3)^{5}$ and murrayamine-A (mukoenine-C) (4), ${ }^{6}$ from the fruits of Clausena lansium. ${ }^{3}$ The fruits of this evergreen tree growing in Southeast Asia are very popular and reported to have health-promoting effects. In fact, biological screenings revealed a remarkable neuroprotective activity of clausenalansine A (1). ${ }^{3}$ Thus, compound 1 might represent a potential lead structure for the development of new agents for the prevention and treatment of neurodegenerative diseases like Parkinson's. ${ }^{3}$

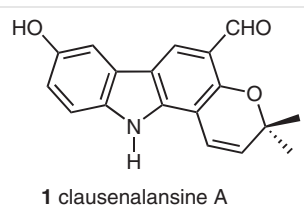

1 clausenalansine $\mathrm{A}$

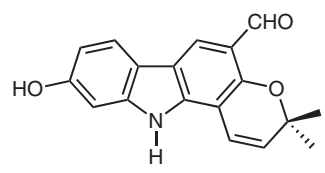

3 clauraila $\mathrm{E}$

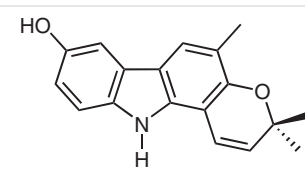

2 koenine

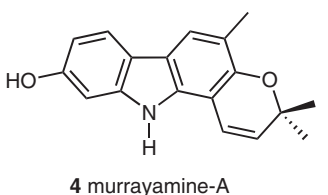

murrayamine-A
Figure 1 Selected monooxygenated pyrano[3,2-a]carbazole alkaloids

Clausenalansine A (1) is an oxidized derivative of koenine (2), a known pyrano[3,2-a]carbazole alkaloid first isolated by Narasimhan and co-workers from the leaves of Murraya koenigii. ${ }^{4}$ In 2016, we described an efficient palladium-catalyzed total synthesis of koenine $(2) .{ }^{7}$ The two related alkaloids, clauraila E (3) and murrayamine-A (4), 5,6 were previously also synthesized by our group. ${ }^{8,9}$ In the present work, ${ }^{10}$ we describe the first synthesis of clausenalansine $A(\mathbf{1})$ and an investigation of its X-ray crystal structure.

Retrosynthetic analysis of clausenalansine A (1) leads to silyl-protected koenine $\mathbf{5}$ as precursor which by oxidation of the methyl group and subsequent deprotection should afford 1 (Scheme 1). The pyrano[3,2-a]carbazole 5 would 
derive from the orthogonally diprotected 2,6-dihydroxycarbazole 6 via regioselective deprotection of the 2-hydroxy group and annulation of the pyran ring. Compound $\mathbf{6}$ can be prepared from the protected $p$-bromophenol $\mathbf{7}$ and arylamine 8 via a sequence of Buchwald-Hartwig coupling ${ }^{11}$ and palladium(II)-catalyzed oxidative cyclization., ${ }^{712}$

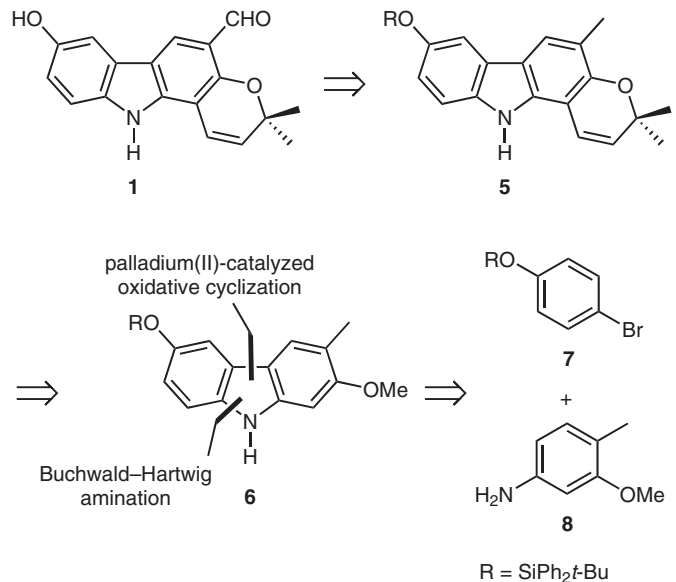

Scheme 1 Retrosynthetic analysis of clausenalansine A (1)

The two starting materials were readily available. Silylation of commercially available 4-bromophenol provided silyl-protected $p$-bromophenol $\mathbf{7}$ and Béchamp reduction of 2-methoxy-4-nitrotoluene gave 3-methoxy-4-methylaniline (8), ${ }^{7,13}$ Buchwald-Hartwig coupling of compound 7 with arylamine $\mathbf{8}$ in the presence of catalytic amounts of DavePhos [2-dicyclohexylphosphino-2'-( N,N-dimethylamino)biphenyl] afforded diarylamine 9 (Scheme 2). Palladium(II)-catalyzed oxidative cyclization of $\mathbf{9}$ using pivalic acid as solvent under microwave conditions provided the orthogonally diprotected 2,6-dihydroxycarbazole 6 . The present protocol for this transformation is better scalable and reproducible compared to the previous one. ${ }^{7}$ Cleavage of the methyl ether of $\mathbf{6}$ using boron tribromide afforded 2-hydroxycarbazole 10. Annulation of the pyran moiety by treatment with prenal and titanium tetraisopropoxide following Casiraghi's method ${ }^{13,14}$ assembled the pyrano[3,2a]carbazole framework and led to silyl-protected koenine $\mathbf{5}$. Subsequently, we investigated the oxidation of $\mathbf{5}$ with 2,3dichloro-5,6-dicyano-1,4-benzoquinone (DDQ) to the corresponding formyl derivative $\mathbf{1 1}$ (Table 1 ). Using 2.2 equivalents of the oxidizing agent and our previously optimized conditions (reaction in a solvent mixture of $\mathrm{MeOH}, \mathrm{THF}$, and $\mathrm{H}_{2} \mathrm{O}$ at room temperature), ${ }_{1}^{15}$ the conversion proceeded surprisingly fast. However, after a reaction time of 1 hour, compound $\mathbf{1 1}$ was obtained in only $37 \%$ yield with no recovered starting material. A lower reaction temperature $\left(0^{\circ} \mathrm{C}\right)$ led to an increase of the yield to $80 \%$. Further attempts to improve the yield by extension of the reaction time gave no better results.
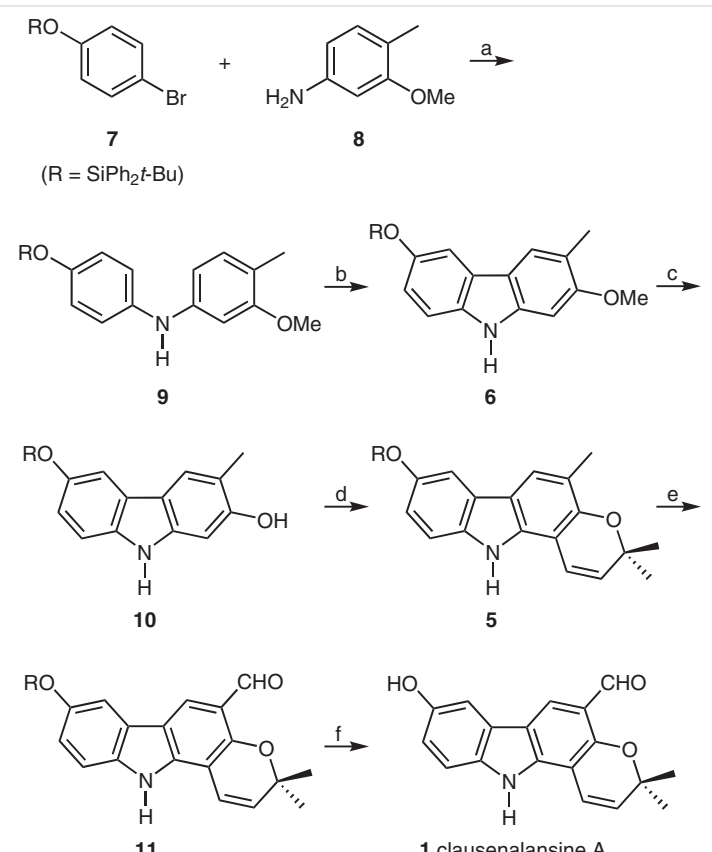

11

1 clausenalansine $A$

Scheme 2 Synthesis of clausenalansine A (1). Reagents and conditions: a) 8 (1.3 equiv), $\mathrm{Pd}_{2}(\mathrm{dba})_{3}$ (6 mol\%), DavePhos ( $\left.13 \mathrm{~mol} \%\right), \mathrm{NaOt}$-Bu (1.5 equiv), toluene, reflux, $16 \mathrm{~h}$ (93\%); b) $\mathrm{Pd}(\mathrm{OAc})_{2}(21 \mathrm{~mol} \%), \mathrm{Cu}(\mathrm{OAc})_{2}$ (2.6 equiv), $\left.\mathrm{PivOH}, 130{ }^{\circ} \mathrm{C}, \mathrm{MW}(300 \mathrm{~W}), 1 \mathrm{~h}(70 \%) ; \mathrm{c}\right) \mathrm{BBr}_{3}$ (5.0 equiv), $\mathrm{CH}_{2} \mathrm{Cl}_{2},-78^{\circ} \mathrm{C}$ to r.t., $26 \mathrm{~h}(80 \%)$; d) prenal (2.2 equiv), $\mathrm{Ti}(\mathrm{Oi}-\mathrm{Pr})_{4}$ (3.9 equiv), toluene, $-78^{\circ} \mathrm{C}$ to r.t., $4 \mathrm{~h}(72 \%)$; e) DDQ (2.2 equiv), $\mathrm{MeOH} / \mathrm{THF} / \mathrm{H}_{2} \mathrm{O}(10: 3: 1), 0^{\circ} \mathrm{C}, 1 \mathrm{~h}(80 \%)$; f) $\operatorname{TBAF}$ (1.2 equiv), DMF, $-5{ }^{\circ} \mathrm{C}$, $20 \min (99 \%)$

Table 1 Oxidation of Silyl-Protected Koenine 5 to Formyl Derivative 11

\begin{tabular}{ll}
\hline Reagents and conditions & Yield (\%) of $\mathbf{1 1}$ \\
\hline $\mathrm{DDQ}$ (2.2 equiv), $\mathrm{MeOH} / \mathrm{THF} / \mathrm{H}_{2} \mathrm{O}(10: 3: 1)$, r.t., $1 \mathrm{~h}$ & 37 \\
$\mathrm{DDQ}$ (2.2 equiv), $\mathrm{MeOH} / \mathrm{THF} / \mathrm{H}_{2} \mathrm{O}(10: 3: 1), 0^{\circ} \mathrm{C}, 1 \mathrm{~h}$ & 80 \\
$\mathrm{DDQ}$ (2.2 equiv), $\mathrm{MeOH} / \mathrm{THF} / \mathrm{H}_{2} \mathrm{O}(10: 3: 1), 0{ }^{\circ} \mathrm{C}, 2 \mathrm{~h}$ & 70 \\
\hline
\end{tabular}

Finally, deprotection of the hydroxyl group of $\mathbf{1 1}$ by reaction with tetrabutylammonium fluoride (TBAF) in DMF provided clausenalansine A (1). A comparison of the spectroscopic data of our synthetic 1 with those described for the isolated natural product showed a perfect agreement. ${ }^{3}$

The structure of clausenalansine $A(\mathbf{1})$ has been additionally confirmed by an X-ray crystal structure determination of single crystals (Figure 2). ${ }^{16}$

The crystal contains two independent molecules A and $B$ in the asymmetric part of the unit cell, which are bound by weak $\mathrm{C}-\mathrm{H} \cdots \pi$ and $\mathrm{N}-\mathrm{H} \cdots \pi$ hydrogen bonds (Figure 3 ). Symmetrically equivalent molecules are bound by strong hydrogen bonds and form 'head-to-tail' dimers (Figure 4). Moreover, symmetrically equivalent molecules in the crystal form stack via $\pi \cdots \pi$ interactions with a distance between 


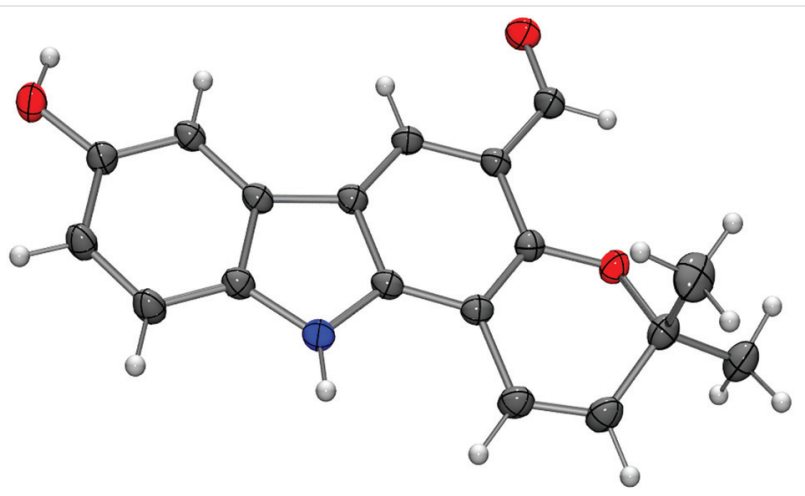

Figure 2 Molecular structure of clausenalansine A (1) in the crystal (triclinic, $P 1$ ); ORTEP plot showing thermal ellipsoids at the $50 \%$ probability level.

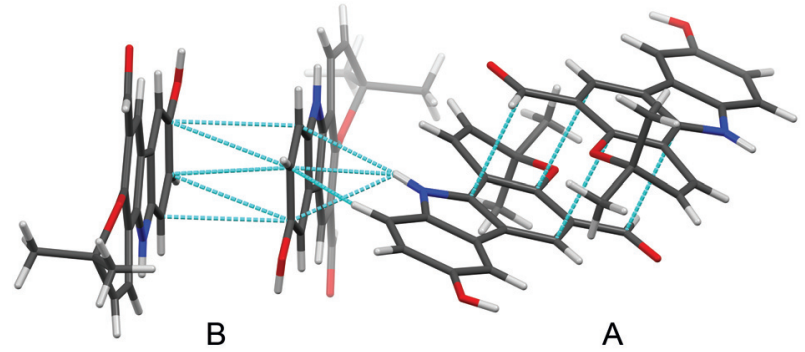

Figure 3 Intermolecular contacts of A and B molecules in the crystal showing $\pi \cdots \pi, \mathrm{N}-\mathrm{H} \cdots \pi$, and $\mathrm{C}-\mathrm{H} \cdots \pi$ interactions

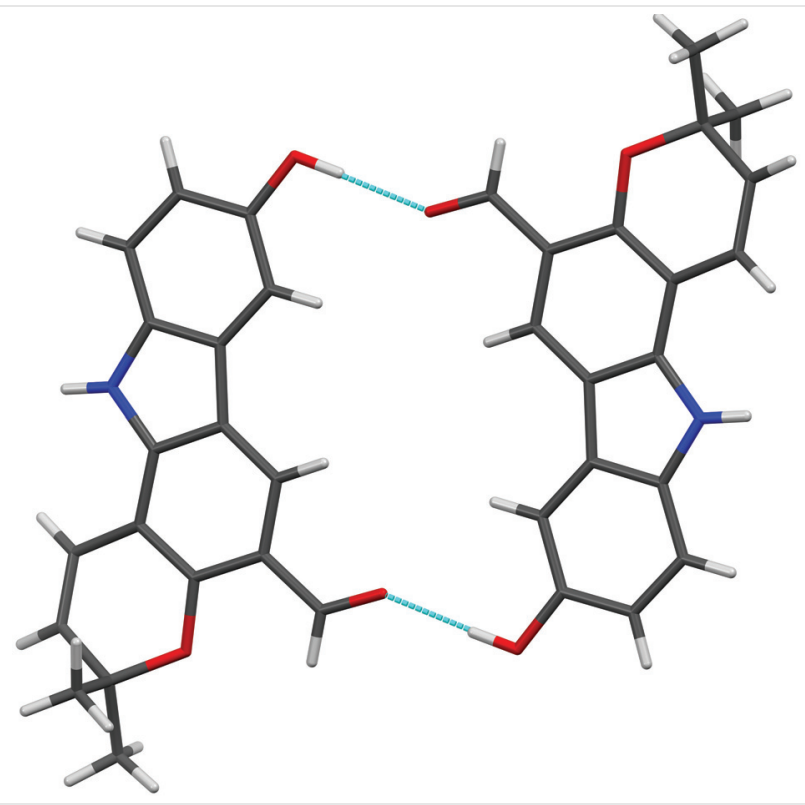

Figure 4 Head-to-tail dimers of clausenalansine A (1) in the crystal
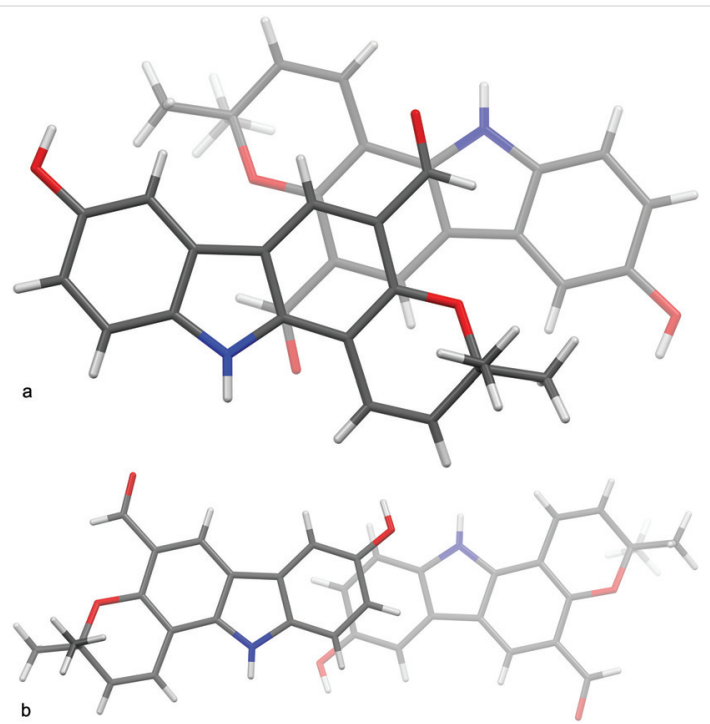

Figure 5 Top views of a fragment of the crystal packing showing the overlap of two independent molecules of A (a) and B (b)

the interacting carbon atoms and the planes of the neighboring carbazole fragments of about $3.4 \AA$ (A molecules) and $3.3 \AA$ (B molecules). It is noteworthy that the A molecules exhibit an ideal 'ring-over-atom' overlap of the inner six-membered rings (Figure 5a), whereas the B molecules overlap with their terminal benzo rings (Figure $5 b$ ).

In conclusion, we have described the first total synthesis of clausenalansine A (1) in seven steps and 30\% overall yield starting from commercially available 4-bromophenol. Our synthetic approach includes the following key steps: Buchwald-Hartwig coupling, palladium(II)-catalyzed oxidative cyclization, Lewis acid promoted annulation of the pyran ring, and oxidation of a methyl group. The spectroscopic data of our synthetic clausenalansine $A$ are in good agreement with those reported by Fu and co-workers for the natural product. ${ }^{3}$ Thus, our total synthesis confirms the structural assignment for the natural product. Additionally, we have investigated the crystal structure of clausenalansine A (1) by X-ray analysis which has revealed a remarkable packing motif formed by $\pi \cdots \pi, \mathrm{N}-\mathrm{H} \cdots \pi$, and $\mathrm{C}-\mathrm{H} \cdots \pi$ interactions.

All reactions were carried out in oven-dried glassware under argon atmosphere using anhydrous solvents, unless stated otherwise. $\mathrm{Pd}(\mathrm{OAc})_{2}$ was recrystallized from glacial acetic acid. All other chemicals were used as received from commercial sources. Microwave irradiations were carried out using a CEM DISCOVER microwave apparatus with a maximum power of $300 \mathrm{~W}$ and a maximum pressure of 20 bar. Flash chromatography was performed using silica gel from Acros Organics (0.035-0.070 mm). TLC was performed with TLC plates from Merck $\left(60 \mathrm{~F}_{254}\right)$ using UV light for visualization. Melting points were measured on a Gallenkamp MPD 350 melting point apparatus. Ultraviolet spectra were recorded on a PerkinElmer $25 \mathrm{UV} / \mathrm{Vis}$ spectro- 
meter. Fluorescence spectra were obtained using a Varian Cary Eclipse spectrometer. IR spectra were recorded on a Thermo Nicolet Avatar FT-IR spectrometer using the ATR method. NMR spectra were recorded on Bruker DXR 500 and Avance III 600 spectrometers. Chemical shifts $\delta$ are reported in ppm with the solvent signal as internal standard. Standard abbreviations are used to denote the multiplicities of the signals. EI mass spectra were recorded by GC-MS coupling using an Agilent Technologies 6890 N GC System equipped with a 5973 Mass Selective Detector $(70 \mathrm{eV})$. ESI mass spectra were recorded on an Esquire LC system with an ion trap detector from Bruker; positive and negative ions were detected. Elemental analyses were measured on a EuroVector EuroEA3000 elemental analyzer. The X-ray crystal structure analysis was performed with a Bruker AXS D8 Venture instrument.

\section{4-Bromophenyl tert-Butyldiphenylsilyl Ether (7)}

Imidazole ( $2.37 \mathrm{~g}, 34.8 \mathrm{mmol})$ was added to a solution of 4-bromophenol (3.05 g, $17.6 \mathrm{mmol}$ ) in DMF (36 mL) and the mixture was stirred for $10 \mathrm{~min}$ at r.t., before $t-\mathrm{BuPh}_{2} \mathrm{SiCl}(7.0 \mathrm{~mL}, 7.4 \mathrm{~g}, 27 \mathrm{mmol})$ was added dropwise. The mixture was stirred for a further $19 \mathrm{~h}$ at r.t. and then aq $1 \mathrm{M} \mathrm{HCl}(40 \mathrm{~mL})$ was added. The aqueous layer was separated and extracted with $\mathrm{CH}_{2} \mathrm{Cl}_{2}$. The combined organic layers were washed with sat. aq $\mathrm{NH}_{4} \mathrm{Cl}$, then with brine, and dried over $\mathrm{MgSO}_{4}$. Removal of the solvent in vacuo and column chromatography (silica gel, isohexane/EtOAc, 15:1 to 12:1) of the residue provided compound 7 as a colorless oil; yield: $7.24 \mathrm{~g}(100 \%)$.

${ }^{1} \mathrm{H}$ NMR $\left(500 \mathrm{MHz}, \mathrm{CDCl}_{3}\right): \delta=1.09(\mathrm{~s}, 9 \mathrm{H}), 6.61-6.64(\mathrm{~m}, 2 \mathrm{H}), 7.15-$ 7.18 (m, 2 H), 7.35-7.38 (m, 4 H), 7.41-7.45 (m, 2 H), 7.68-7.69 (m, 4 $\mathrm{H})$.

${ }^{13} \mathrm{C}$ NMR and DEPT (125 MHz, $\left.\mathrm{CDCl}_{3}\right): \delta=19.40(\mathrm{C}), 26.42\left(3 \mathrm{CH}_{3}\right)$, $113.32(\mathrm{C}), 121.46(2 \mathrm{CH}), 127.84(4 \mathrm{CH}), 130.03(2 \mathrm{CH}), 132.06(2 \mathrm{CH})$, 132.40 (2 C), $135.44(4 \mathrm{CH}), 154.72(\mathrm{C})$.

MS (EI): $m / z(\%)=412(9), 410\left(9,\left[\mathrm{M}^{+}\right]\right), 355$ (100), 353 (100), 273 (76), 197 (29), 152 (23), 57 (25).

For further spectroscopic data, see ref. 7.

\section{$N$-[4-(tert-Butyldiphenylsilyloxy)phenyl]-3-methoxy-4-methyl- aniline (9)}

A solution of bromoarene $7(2.01 \mathrm{~g}, 4.89 \mathrm{mmol})$ in toluene $(28 \mathrm{~mL})$ was added to a vigorously stirred solution of 3-methoxy-4-methylaniline $(8)^{13}(878 \mathrm{mg}, 6.40 \mathrm{mmol}), \mathrm{Pd}_{2}(\mathrm{dba})_{3}(260 \mathrm{mg}, 284 \mu \mathrm{mol})$, DavePhos (248 mg, $630 \mu \mathrm{mol})$, and $\mathrm{NaOt}$-Bu (701 mg, $7.29 \mathrm{mmol})$ in toluene $(66 \mathrm{~mL})$ at reflux temperature. Stirring was continued at reflux for $16 \mathrm{~h}$ under argon and then for $4 \mathrm{~h}$ at r.t. under air. The reaction mixture was filtered over Celite and washed with EtOAc. The organic layer was washed with brine, dried over $\mathrm{MgSO}_{4}$, and concentrated in vacuo. Column chromatography (silica gel, isohexane/EtOAc, 20:1) of the residue provided diarylamine $\mathbf{9}$ as a brown viscous oil; yield: $2.12 \mathrm{~g}$ (93\%).

${ }^{1} \mathrm{H}$ NMR (500 MHz, DMSO- $d_{6}$ ): $\delta=1.01$ (s, $9 \mathrm{H}$ ), 1.98 (s, $3 \mathrm{H}$ ), 3.64 (s, 3 $\mathrm{H}), 6.37(\mathrm{dd}, J=7.9,2.2 \mathrm{~Hz}, 1 \mathrm{H}), 6.43(\mathrm{dd}, J=2.2,0.3 \mathrm{~Hz}, 1 \mathrm{H}), 6.59-$ $6.62(\mathrm{~m}, 2 \mathrm{H}), 6.79-6.82(\mathrm{~m}, 2 \mathrm{H}), 6.84(\mathrm{~d}, J=8.2 \mathrm{~Hz}, 1 \mathrm{H}), 7.39-7.46$ (m, $6 \mathrm{H}), 7.63-7.67(\mathrm{~m}, 5 \mathrm{H})$.

${ }^{13} \mathrm{C}$ NMR and DEPT (125 MHz, DMSO- $\left.d_{6}\right): \delta=15.33\left(\mathrm{CH}_{3}\right), 18.94(\mathrm{C})$, $26.38\left(3 \mathrm{CH}_{3}\right), 54.80\left(\mathrm{CH}_{3}\right), 99.13(\mathrm{CH}), 106.98(\mathrm{CH}), 115.62(\mathrm{C}), 118.90$ (2 CH), $119.76(2 \mathrm{CH}), 127.96(4 \mathrm{CH}), 130.10(2 \mathrm{CH}), 130.49(\mathrm{CH})$, 132.48 (2 C), 135.09 (4 CH), 137.41 (C), 143.72 (C), 148.48 (C), 157.77 (C).

MS (EI): $m / z(\%)=467$ (98, [M+]), 410 (100), 205 (17), 136 (21).

For further spectroscopic data, see ref. 7.

\section{6-(tert-Butyldiphenylsilyloxy)-2-methoxy-3-methyl-9H-carba- zole (6)}

Method A: A microwave reaction vial (10 mL pressure vessel, Pyrex, CEM Discover) was filled with diarylamine $9(57.1 \mathrm{mg}, 122 \mu \mathrm{mol})$, $\mathrm{Pd}(\mathrm{OAc})_{2}(5.8 \mathrm{mg}, 26 \mu \mathrm{mol}), \mathrm{Cu}(\mathrm{OAc})_{2}(57.6 \mathrm{mg}, 317 \mu \mathrm{mol})$, and PivOH (376 mg) under air, and the mixture was heated at $130^{\circ} \mathrm{C}$ by microwave irradiation $(300 \mathrm{~W}$ ) for $1 \mathrm{~h}$. After cooling to r.t., the mixture was washed with sat. aq $\mathrm{K}_{2} \mathrm{CO}_{3}$ and the aqueous layer was extracted several times with EtOAc. The combined organic layers were washed with brine, dried over $\mathrm{MgSO}_{4}$, and concentrated in vacuo. Column chromatography (silica gel, pentane/EtOAc, 9:1 to 5:1) of the residue provided carbazole 6 as a brown viscous oil; yield: $39.7 \mathrm{mg}$ (70\%).

Method B: A round-bottom flask was filled with diarylamine $\mathbf{9}(3.29 \mathrm{~g}$, $7.03 \mathrm{mmol}$ ), $\mathrm{Pd}(\mathrm{OAc})_{2}$ (332 mg, $1.48 \mathrm{mmol}$ ), $\mathrm{Cu}(\mathrm{OAc})_{2}$ (3.30 g, 18.2 $\mathrm{mmol})$, and $\mathrm{PivOH}(22.0 \mathrm{~g})$ under air, and the mixture was heated at $130{ }^{\circ} \mathrm{C}$ for $2 \mathrm{~h}$ while stirring vigorously. After cooling to r.t., the mixture was washed with sat. aq $\mathrm{K}_{2} \mathrm{CO}_{3}$ and the aqueous layer was extracted several times with EtOAc. The combined organic layers were washed with brine and dried over $\mathrm{MgSO}_{4}$. Removal of the solvent and column chromatography (silica gel, pentane/EtOAc, 9:1 to 5:1) of the residue afforded carbazole 6 as a brown viscous oil; yield: $1.64 \mathrm{~g}$ (50\%).

${ }^{1} \mathrm{H}$ NMR $\left(500 \mathrm{MHz}\right.$, DMSO- $\left.d_{6}\right): \delta=1.05(\mathrm{~s}, 9 \mathrm{H}), 2.18(\mathrm{~s}, 3 \mathrm{H}), 3.81(\mathrm{~s}, 3$ $\mathrm{H}), 6.65(\mathrm{dd}, J=8.5,2.6 \mathrm{~Hz}, 1 \mathrm{H}), 6.84(\mathrm{~s}, 1 \mathrm{H}), 7.10(\mathrm{~d}, J=8.5 \mathrm{~Hz}, 1 \mathrm{H})$, $7.30(\mathrm{~d}, J=2.5 \mathrm{~Hz}, 1 \mathrm{H}), 7.38-7.46(\mathrm{~m}, 6 \mathrm{H}), 7.53(\mathrm{~s}, 1 \mathrm{H}), 7.69-7.70(\mathrm{~m}$, $4 \mathrm{H}), 10.73$ (s, $1 \mathrm{H})$.

${ }^{13} \mathrm{C}$ NMR and DEPT (125 MHz, DMSO- $\left.d_{6}\right): \delta=16.97\left(\mathrm{CH}_{3}\right), 19.51(\mathrm{C})$, $26.93\left(3 \mathrm{CH}_{3}\right), 55.70\left(\mathrm{CH}_{3}\right), 92.98(\mathrm{CH}), 109.04(\mathrm{CH}), 111.12(\mathrm{CH})$, $115.38(\mathrm{C}), 116.52(\mathrm{CH}), 117.43(\mathrm{C}), 121.46(\mathrm{CH}), 123.50(\mathrm{C}), 128.37$ (4 $\mathrm{CH}), 130.47$ (2 CH), 133.27 (2 C), 135.01 (C), 135.59 (4 CH), 140.77 (C), $148.33(\mathrm{C}), 157.24(\mathrm{C})$.

MS (EI): $m / z(\%)=465$ (51, [M+1), 408 (100), 330 (8), 204 (12).

For further spectroscopic data, see ref. 7.

\section{6-(tert-Butyldiphenylsilyloxy)-2-hydroxy-3-methyl-9H-carbazole} (10)

To a solution of carbazole $\mathbf{6}(51.9 \mathrm{mg}, 111 \mu \mathrm{mol})$ in $\mathrm{CH}_{2} \mathrm{Cl}_{2}(7.5 \mathrm{~mL})$ at $-78{ }^{\circ} \mathrm{C}$ was added $1 \mathrm{M} \mathrm{BBr}_{3}$ in $\mathrm{CH}_{2} \mathrm{Cl}_{2}(0.56 \mathrm{~mL}, 560 \mu \mathrm{mol})$ dropwise over a period of $20 \mathrm{~min}$. Stirring was continued for $30 \mathrm{~min}$ at $-78{ }^{\circ} \mathrm{C}$ and then for $2 \mathrm{~h}$ at $-10^{\circ} \mathrm{C}$. The mixture was allowed to warm to r.t. and stirred for a further $23 \mathrm{~h}$. Then, $\mathrm{MeOH}(5.0 \mathrm{~mL})$ was added under cooling. The organic layer was washed with water and brine, and the combined aqueous layers were extracted with $\mathrm{CH}_{2} \mathrm{Cl}_{2}$. The combined organic layers were dried over $\mathrm{MgSO}_{4}$ and concentrated in vacuo. Column chromatography (silica gel, pentane/EtOAc, 4:1) of the residue provided 2-hydroxycarbazole $\mathbf{1 0}$ as a brown viscous oil; yield: 39.9 $\mathrm{mg}(80 \%)$.

${ }^{1} \mathrm{H}$ NMR $\left(500 \mathrm{MHz}\right.$, DMSO- $\left.d_{6}\right): \delta=1.04(\mathrm{~s}, 9 \mathrm{H}), 2.15(\mathrm{~s}, 3 \mathrm{H}), 6.62(\mathrm{dd}$, $J=8.6,2.6 \mathrm{~Hz}, 1 \mathrm{H}), 6.75(\mathrm{~s}, 1 \mathrm{H}), 7.03(\mathrm{~d}, J=8.6 \mathrm{~Hz}, 1 \mathrm{H}), 7.25(\mathrm{~d}, J=2.1$ Hz, 1 H), 7.38-7.44 (m, 7 H), 7.68-7.70 (m, 4 H), 9.31 (s, 1 H), 10.53 (s, $1 \mathrm{H})$.

${ }^{13} \mathrm{C}$ NMR and DEPT (125 MHz, DMSO- $\left.d_{6}\right): \delta=16.43\left(\mathrm{CH}_{3}\right), 19.06(\mathrm{C})$, $26.49\left(3 \mathrm{CH}_{3}\right), 95.85(\mathrm{CH}), 108.41(\mathrm{CH}), 110.36(\mathrm{CH}), 114.64(\mathrm{C})$, $115.65(\mathrm{CH}), 115.97(\mathrm{C}), 121.01(\mathrm{CH}), 123.38(\mathrm{C}), 127.91(4 \mathrm{CH})$, $130.00(2 \mathrm{CH}), 132.87$ (2 C), 134.51 (C), 135.15 (4 CH), $140.51(\mathrm{C})$, $147.74(\mathrm{C}), 154.75(\mathrm{C})$.

MS (EI): $m / z(\%)=451\left(47,\left[\mathrm{M}^{+}\right]\right), 394$ (100), 316 (14), 197 (24).

For further spectroscopic data, see ref. 7 . 


\section{8-(tert-Butyldiphenylsilyloxy)-3,3,5-trimethyl-3,11-dihydropyra-} no[3,2-a]carbazole (5)

To a stirred solution of 2-hydroxycarbazole $\mathbf{1 0}(70.3 \mathrm{mg}, 156 \mu \mathrm{mol})$ in toluene $(3.0 \mathrm{~mL})$ at $-78{ }^{\circ} \mathrm{C}$ was added 3-methylbut-2-enal (prenal) $(28.7 \mathrm{mg}, 341 \mu \mathrm{mol})$ and then slowly $\mathrm{Ti}(\mathrm{Oi}-\mathrm{Pr})_{4}(0.18 \mathrm{~mL}, 0.17 \mathrm{~g}, 0.61$ $\mathrm{mmol}$ ). The reaction mixture was stirred for $10 \mathrm{~min}$ at $-78^{\circ} \mathrm{C}$, then allowed to warm to r.t., and stirred for an additional $4 \mathrm{~h}$. After hydrolysis by addition of water $(3.0 \mathrm{~mL})$, the organic layer was separated, and washed first with sat. aq $\mathrm{NH}_{4} \mathrm{Cl}$ and then with water. The combined aqueous layers were extracted with EtOAc and the combined organic layers were then washed with brine and dried over $\mathrm{MgSO}_{4}$. Removal of the solvent and column chromatography (silica gel, pentane/EtOAc, 8:1) of the residue provided pyrano[3,2-a]carbazole 5 as a yellow viscous oil; yield: $58.4 \mathrm{mg}$ (72\%).

${ }^{1} \mathrm{H}$ NMR (500 MHz, DMSO- $d_{6}$ ): $\delta=1.07(\mathrm{~s}, 9 \mathrm{H}), 1.40(\mathrm{~s}, 6 \mathrm{H}), 2.18(\mathrm{~s}, 3$ H), $5.75(\mathrm{dd}, J=9.8,0.4 \mathrm{~Hz}, 1 \mathrm{H}), 6.70(\mathrm{ddd}, J=8.5,2.5,0.3 \mathrm{~Hz}, 1 \mathrm{H})$, $6.85(\mathrm{~d}, J=9.8 \mathrm{~Hz}, 1 \mathrm{H}), 7.13(\mathrm{dd}, J=8.5,0.3 \mathrm{~Hz}, 1 \mathrm{H}), 7.33(\mathrm{dd}, J=2.5$, $0.3 \mathrm{~Hz}, 1 \mathrm{H}), 7.41-7.46$ (m, $7 \mathrm{H}), 7.71-7.73(\mathrm{~m}, 4 \mathrm{H}), 10.94(\mathrm{~s}, 1 \mathrm{H})$.

${ }^{13} \mathrm{C}$ NMR and DEPT (125 MHz, DMSO- $\left.d_{6}\right): \delta=15.86\left(\mathrm{CH}_{3}\right), 19.12(\mathrm{C})$, $26.53\left(3 \mathrm{CH}_{3}\right), 27.38\left(2 \mathrm{CH}_{3}\right), 75.63(\mathrm{C}), 104.28(\mathrm{C}), 108.82(\mathrm{CH}), 110.78$ $(\mathrm{CH}), 115.81(\mathrm{C}), 116.45(\mathrm{C}, \mathrm{CH}), 117.88(\mathrm{CH}), 120.86(\mathrm{CH}), 123.38(\mathrm{C})$, $127.98(4 \mathrm{CH}), 128.89(\mathrm{CH}), 130.08(2 \mathrm{CH}), 132.86(2 \mathrm{C}), 134.88(\mathrm{C})$, 135.21 (4 CH), 135.98 (C), 148.09 (C), 149.03 (C).

MS (EI): $m / z(\%)=517\left(33,\left[\mathrm{M}^{+}\right]\right), 503$ (75), 502 (100), 460 (19), 444 (17), 222 (28).

For further spectroscopic data, see ref. 7 .

\section{8-(tert-Butyldiphenylsilyloxy)-5-formyl-3,3-dimethyl-3,11-di- hydropyrano[3,2-a]carbazole (11)}

Pyrano[3,2-a]carbazole $5(93.1 \mathrm{mg}, 180 \mu \mathrm{mol})$ was dissolved in a mixture of $\mathrm{MeOH} / \mathrm{THF} / \mathrm{H}_{2} \mathrm{O}(10: 3: 1,21 \mathrm{~mL})$ and the solution was cooled to $0{ }^{\circ} \mathrm{C}$. DDQ $(92.5 \mathrm{mg}, 407 \mu \mathrm{mol})$ was then added in portions and stirring was continued for $1 \mathrm{~h}$ at $0{ }^{\circ} \mathrm{C}$. The reaction was quenched by addition of $10 \%$ aq $\mathrm{NaOH}$, and the aqueous layer was separated and extracted with EtOAc. The combined organic layers were washed with brine, dried over $\mathrm{MgSO}_{4}$, and concentrated in vacuo. Column chromatography (silica gel, pentane/EtOAc, 5:1 to 3:1) of the residue provided compound 11 as a light-yellow solid; yield: $76.5 \mathrm{mg}$ (80\%); mp 234-234. $5^{\circ} \mathrm{C}$.

IR (ATR): 3281, 2959, 2929, 2855, 1589, 1460, 1139, 1114, 970, 890, $699,613 \mathrm{~cm}^{-1}$.

${ }^{1} \mathrm{H}$ NMR (600 MHz, DMSO- $\left.d_{6}\right): \delta=1.08(\mathrm{~s}, 9 \mathrm{H}), 1.48$ (s, $\left.6 \mathrm{H}\right), 5.91$ (d, $J$ $=9.9 \mathrm{~Hz}, 1 \mathrm{H}), 6.77(\mathrm{dd}, J=8.7,2.3 \mathrm{~Hz}, 1 \mathrm{H}), 6.89(\mathrm{~d}, J=9.9 \mathrm{~Hz}, 1 \mathrm{H})$, $7.21(\mathrm{dd}, J=8.7,0.4 \mathrm{~Hz}, 1 \mathrm{H}), 7.42-7.48(\mathrm{~m}, 6 \mathrm{H}), 7.54(\mathrm{~d}, J=2.3 \mathrm{~Hz}, 1$ H), 7.71-7.73 (m, $4 \mathrm{H}), 8.11$ (s, $1 \mathrm{H}), 10.31(\mathrm{~s}, 1 \mathrm{H}), 11.57$ (s, $1 \mathrm{H})$.

${ }^{13} \mathrm{C}$ NMR and DEPT (151 MHz, DMSO- $\left.d_{6}\right): \delta=19.13(\mathrm{C}), 26.52\left(3 \mathrm{CH}_{3}\right)$, $27.22\left(2 \mathrm{CH}_{3}\right), 77.13(\mathrm{C}), 104.13(\mathrm{C}), 110.14(\mathrm{CH}), 111.48(\mathrm{CH}), 116.77$ $(\mathrm{CH}), 117.25(2 \mathrm{C}), 117.37(\mathrm{C}), 118.12(\mathrm{CH}), 119.27(\mathrm{CH}), 123.88(\mathrm{C})$, $128.03(4 \mathrm{CH}), 129.93(\mathrm{CH}), 130.17(2 \mathrm{CH}), 132.63(\mathrm{C}), 135.23(4 \mathrm{CH})$, 135.68 (C), 141.22 (C), 149.18 (C), 153.77 (C), 187.91 (CHO).

MS (ESI, +50 V): $m / z=532.6\left[\mathrm{M}+\mathrm{H}^{+}\right]$.

UV (MeOH): $\lambda=224,288,311,370(\mathrm{sh}) \mathrm{nm}$.

Fluorescence $(\mathrm{MeOH}): \lambda_{\mathrm{ex}}=311 \mathrm{~nm}, \lambda_{\mathrm{em}}=358 \mathrm{~nm}$.

Anal. Calcd for $\mathrm{C}_{34} \mathrm{H}_{33} \mathrm{NO}_{3} \mathrm{Si}$ : C, 76.80; H, 6.26; N, 2.63. Found: C, $76.61 ; \mathrm{H}, 6.17 ; \mathrm{N}, 2.67$.

\section{Clausenalansine A (1)}

A solution of compound 11 (30.4 mg, $57.2 \mu \mathrm{mol})$ in DMF $(1.75 \mathrm{~mL})$ was stirred at $-5^{\circ} \mathrm{C}$ under air and $1 \mathrm{M} \mathrm{TBAF}$ in THF $(70 \mu \mathrm{L}, 70 \mu \mathrm{mol})$ was added dropwise. The reaction mixture was stirred for $20 \mathrm{~min}$ at $-5{ }^{\circ} \mathrm{C}$ and then water was added under cooling. The solution was diluted with EtOAc, and the organic layer was separated and washed with water and brine. The combined aqueous layers were extracted with EtOAc and the combined organic layers were dried over $\mathrm{MgSO}_{4}$. Removal of the solvent and column chromatography (silica gel, pentane/EtOAc, 2:1, $1 \mathrm{vol} \% \mathrm{AcOH}$ ) of the residue provided $\mathbf{1}$ as a yellow solid; yield: $16.7 \mathrm{mg}$ (99\%); $\mathrm{mp}>240{ }^{\circ} \mathrm{C}$ (dec).

IR (ATR): 3413, 3393, 3298, 2972, 2868, 2030, 2010, 1658, 1639, 1586 , $1464,1258,1146,1116,891,866,802,718,679 \mathrm{~cm}^{-1}$.

${ }^{1} \mathrm{H}$ NMR $\left(600 \mathrm{MHz}\right.$, DMSO- $d_{6}$ ): $\delta=1.49(\mathrm{~s}, 6 \mathrm{H}), 5.91(\mathrm{~d}, J=9.8 \mathrm{~Hz}, 1$ $\mathrm{H}), 6.87(\mathrm{dd}, J=8.6,2.3 \mathrm{~Hz}, 1 \mathrm{H}), 6.91(\mathrm{~d}, J=9.8 \mathrm{~Hz}, 1 \mathrm{H}), 7.27$ (d, $J=8.6$ $\mathrm{Hz}, 1 \mathrm{H}), 7.40$ (dd, J = 2.3, $0.4 \mathrm{~Hz}, 1 \mathrm{H}), 8.20$ (d, J = 0.4 Hz, $1 \mathrm{H}), 9.08(\mathrm{br}$ $\mathrm{s}, 1 \mathrm{H}), 10.33(\mathrm{~s}, 1 \mathrm{H}), 11.46(\mathrm{~s}, 1 \mathrm{H})$.

${ }^{13} \mathrm{C}$ NMR and DEPT (151 MHz, DMSO- $\left.d_{6}\right): \delta=27.24\left(2 \mathrm{CH}_{3}\right), 77.01(\mathrm{C})$, $103.89(\mathrm{C}), 105.32(\mathrm{CH}), 111.59(\mathrm{CH}), 114.84(\mathrm{CH}), 116.84(\mathrm{CH})$, 116.97 (C), 117.59 (C), $119.17(\mathrm{CH}), 124.00(\mathrm{C}), 129.70(\mathrm{CH}), 134.45$ (C), 141.13 (C), $151.64(\mathrm{C}), 153.59$ (C), $187.86(\mathrm{CHO})$.

MS (EI): $m / z(\%)=293\left(13,\left[\mathrm{M}^{+}\right]\right), 279$ (19), 278 (100), 276 (23), 249 (6), $220(9), 139$ (6).

UV (MeOH): $\lambda=227,288,312,372(\mathrm{sh}) \mathrm{nm}$.

Anal. Calcd for $\mathrm{C}_{18} \mathrm{H}_{15} \mathrm{NO}_{3}$ : C, 73.71; $\mathrm{H}, 5.15 ; \mathrm{N}, 4.78$. Found: C, 73.73; H, 5.29; N, 4.69.

\section{X-ray Crystallographic Data for Compound 1}

Single crystals of clausenalansine A ( $\mathbf{1}$ ) were obtained by crystallization from pentane/MeOH. $\mathrm{C}_{18} \mathrm{H}_{15} \mathrm{NO}_{3}, M=293.31 \mathrm{~g} \mathrm{~mol}^{-1}$, crystal size: $0.090 \times 0.153 \times 0.564 \mathrm{~mm}^{3}$, triclinic, space group: $\overline{\mathrm{1}} \overline{1}, a=8.429(2) \AA$, $b=10.978(3) \AA, c=17.384(4) \AA, \alpha=71.708(9)^{\circ}, \beta=78.951(9)^{\circ}, \gamma=$ 74.748(10) $)^{\circ}, V=1463.0(6) \AA^{3}, Z=4, \rho_{\text {calcd }}=1.332 \mathrm{~g} \mathrm{~cm}^{-3}, \mu=0.091$ $\mathrm{mm}^{-1}, \lambda=0.71073 \AA, T=150(2) \mathrm{K}, \theta$ range $=2.49-28.00^{\circ}$, reflections collected: 71077, independent reflections: $7039\left(R_{\text {int }}=0.0947\right), 6193$ observed reflections $[I \geq 2 \sigma(I)], 418$ parameters. The structure was solved by direct methods and refined by full-matrix least squares on $F^{2}$; final $R$ indices $[I>2 \sigma(I)]: R_{1}=0.0500, w R_{2}=0.1341$; max. residual electron density: 0.540 e $\AA^{-3} .16$

\section{Supporting Information}

Supporting information for this article is available online at https://doi.org/10.1055/s-0040-1706551.

\section{References}

(1) (a) Chakraborty, D. P.; Roy, S. In Progress in the Chemistry of Organic Natural Products, Vol. 57; Herz, W.; Grisebach, H.; Kirby, G. W.; Steglich, W.; Tamm, C., Ed.; Springer-Verlag: Wien, 1991, 71. (b) Chakraborty, D. P. In The Alkaloids, Vol. 44; Cordell, G. A., Ed.; Academic Press: New York, 1993, 257.

(2) (a) Knölker, H.-J.; Reddy, K. R. Chem. Rev. 2002, 102, 4303. (b) Knölker, H.-J. Top. Curr. Chem. 2005, 244, 115. (c) Knölker, H.-J.; Reddy, K. R. In The Alkaloids, Vol. 65; Cordell, G. A., Ed.; Academic Press: Amsterdam, 2008, 1. (d) Bauer, I.; Knölker, H.-J. Top. Curr. Chem. 2012, 309, 203. (e) Schmidt, A. W.; Reddy, K. R.; Knölker, H.-J. Chem. Rev. 2012, 112, 3193. 
(3) Liu, Y.-P.; Guo, J.-M.; Liu, Y.-Y.; Hu, S.; Yan, G.; Qiang, L.; Fu, Y.-H. J. Agric. Food Chem. 2019, 67, 5764.

(4) (a) Narasimhan, N. S.; Paradkar, M. V.; Kelkar, S. L. Indian J. Chem. 1970, 8, 473. (b) Narasimhan, N. S.; Paradkar, M. V.; Chitguppi, V. P.; Kelkar, S. L. Indian J. Chem. 1975, 13, 993.

(5) Sriphana, U.; Thongsri, Y.; Prariyachatigul, C.; Pakawatchai, C.; Yenjai, C. Arch. Pharmacal Res. 2013, 36, 1078.

(6) (a) Wu, T. S. Phytochemistry 1991, 30, 1048. (b) Ito, C.; Thoyama, Y.; Omura, M.; Kajiura, I.; Furukawa, H. Chem. Pharm. Bull. 1993, 41, 2096. (c) Songue, J. L.; Kouam, E. D.; Mpondo, T. N.; White, R. L. Molecules 2012, 17, 13673.

(7) Schuster, C.; Rönnefahrt, M.; Julich-Gruner, K. K.; Jäger, A.; Schmidt, A. W.; Knölker, H.-J. Synthesis 2016, 48, 150.

(8) Hesse, R.; Kataeva, O.; Schmidt, A. W.; Knölker, H.-J. Chem. Eur. J. 2014, 20, 9504.

(9) (a) Julich-Gruner, K. K.; Kataeva, O.; Schmidt, A. W.; Knölker, H.J. Chem. Eur. J. 2014, 20, 8536. (b) Schuster, C.; Julich-Gruner, K. K.; Schnitzler, H.; Hesse, R.; Jäger, A.; Schmidt, A. W.; Knölker, H.-J.J. Org. Chem. 2015, 80, 5666.

(10) Part 147 of Transition Metals in Organic Synthesis; for Part 146, see: Lösle, V.; Knölker, H.-J. Arkivoc 2020, vii, 192.
(11) (a) Charles, M. D.; Schultz, P.; Buchwald, S. L. Org. Lett. 2005, 7, 3965. (b) Surry, D. S.; Buchwald, S. L. Angew. Chem. Int. Ed. 2008, 47, 6338. (c) Ruiz-Castillo, P.; Buchwald, S. L. Chem. Rev. 2016, $116,12564$.

(12) (a) Knölker, H.-J.; O'Sullivan, N. Tetrahedron 1994, 50, 10893. (b) Knölker, H.-J. Chem. Lett. 2009, 38, 8. (c) Gensch, T.; Rönnefahrt, M.; Czerwonka, R.; Jäger, A.; Kataeva, O.; Bauer, I.; Knölker, H.-J. Chem. Eur. J. 2012, 18, 770. (d) Gensch, T.; Richter, N.; Theumer, G.; Kataeva, O.; Knölker, H.-J. Chem. Eur. J. 2016, 22,11186

(13) Hesse, R.; Gruner, K. K.; Kataeva, O.; Schmidt, A. W.; Knölker, H.J. Chem. Eur. J. 2013, 19, 14098.

(14) (a) Bandaranayake, W. M.; Begley, M. J.; Brown, B. O.; Clarke, D. G.; Crombie, L.; Whiting, D. A. J. Chem. Soc., Perkin Trans. 1 1974, 998. (b) Sartori, G.; Casiraghi, G.; Bolzoni, L.; Casnati, G. J. Org. Chem. 1979, 44, 803.

(15) Gruner, K. K.; Hopfmann, T.; Matsumoto, K.; Jäger, A.; Katsuki, T.; Knölker, H.-J. Org. Biomol. Chem. 2011, 9, 2057.

(16) CCDC 2017103 (compound $\mathbf{1}$ ) contains the supplementary crystallographic data for this paper. The data can be obtained free of charge from The Cambridge Crystallographic Data Centre via www.ccdc.cam.ac.uk/getstructures. 